Culture, Personality and Education

МәАәният, шәхес һәм мәгарифр

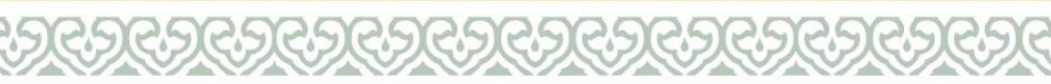

Культура, Аичность и образование

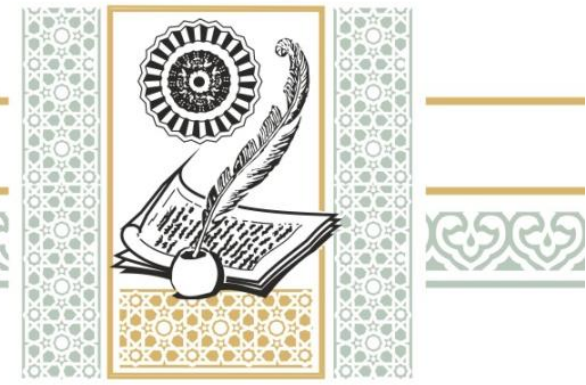

DOI: $10.26907 / 2311-2042-2020-15-2-105-117$

\title{
BULAT GALEEV'S CONTRIBUTION TO THE COMPREHENSIVE STUDY OF ARTISTIC WORKS
}

\author{
Yulduz Galimzyanovna Nigmatullina, \\ Kazan Federal University, \\ 18 Kremlyovskaya Str., Kazan, 420008, Russian Federation, \\ ermakeev@mail.ru.
}

\begin{abstract}
The article outlines Bulat Galeev's contribution to the development of the interuniversity scientific trend, initiated at the Faculty of Philology of Kazan University in the 1970s - 1980s when experts in different fields of science united to implement a system-integrated approach to the phenomena of literature and art. Summarizing the results of the scholar's long-term work, the article gives a brief description of the scientific conception, developed by B. Galeev, the head of the design department "Prometheus", who studied the history and theory of the art of light in Tatarstan.
\end{abstract}

Key words: system-complex study of literature and art, Kazan University, Yu. G. Nigmatullina, B. Galeev, design department "Prometheus", theory of light and music.

A characteristic feature of research in the 1960s - 70s was the trend towards unification of different areas of science to study its fundamental problems. The Humanities also faced the need to comprehensively study literature and art. To this end, in the mid-1960s, the Standing Commission for the Comprehensive Study of Artistic Woks was organized under the Scientific Council for the History of World Culture at the Academy of Sciences of the USSR, headed by Professor B. Meilakh. In April 1979, Kazan University approved the organization of the Kazan base group of the Commission at the USSR Academy of Sciences (the chairman of the Coordinating Council was Doctor of Philology, Prof. Yu. Nigmatullina). The group included researchers, teachers, graduate students of KSU, of the Kazan branch of the USSR Academy of Sciences, of the Kazan Aviation Institute (the design department "Prometheus"), of the Kazan State Pedagogical Institute, of the Institute of Culture, as well as writers and art critics (about 40 people in total) [see: Nigmatullina, 1980], [Nigmatullina, 1992], [Nigmatullina, 2004], [Russkoie literaturovedenie v Kazanskom universitete (18062009)], [Saiapova]).

The group of the design department "Prometheus" in the Kazan Aviation Institute was headed by Bulat Galeev (1940-2009), the great-grandson of the founder of the Kazan madrasah "Mukhamadiya", the nephew of G. Barudi who was the first rector of this madrasah [Galeev, 2020]. Like-minded people and friends remember 
B. Galeev as a very organized, responsible and responsive person. The list of his achievements is very impressive, this indicates that the scientist was a unique person. In 1973, he presented his Ph.D. thesis "Philosophical Problems of LightMusical Synthesis as a Form of Reflecting Reality" [Galeev, 1973]. As a result of his long-term research he completed his doctoral thesis "The Issue of Synesthesia in Art: Philosophical and Aesthetic Analysis" [Galeev, 1985]. B. Galeev is the author of many books ([Galeev, Andreev], [Galeev, 1976], [Galeev, 1978], [Galeev, 1980], [Vanechkina, Galeev], [Galeev, 1982], [Galeev, Zorin, Saifullin], [Galeev, 2002], [Galeev, 2010]), textbooks ([Galeev. Svetomuzyka...], [Galeev. Teatralizovannye ...]) and more than five hundred articles on contemporary art published in Russia and abroad.

B. Galeev was in charge of the group of 10-15 people. From 1993, when the research institute was organized, a comprehensive study at the junctions "art - science - technology" was conducted in an officially planned way, not only "on a voluntary basis". It provided an opportunity to intensify research on the history and theory of the art of light in Tatarstan. Of interest are the fruitful searches for traces of comprehensive research in the history of Kazan science in the past, starting from the turn of the $19^{\text {th }}-20^{\text {th }}$ centuries (research conducted by E. Klyuchevskaya and others). B. Galeev continued his studies of synesthetic metaphors in Russian and foreign poetry. The results of studying the forecasting features of art itself turned out to be promising (S. Sintsova presented her Ph.D. thesis on this topic [Sintsova]). E. Sintsov, who used to belong to the literary group for the comprehensive study of creative works, joined the team as a part time member to study the synesthetic analogy "music ornament" and published a monograph on this topic [Sintsov]. Simultaneously, a group of engineers and students developed equipment for transforming visual and ornamental structures into melodic ones (V. Skorokhodov and others). They studied the artistic features and technology of such new musical formations as "spatial music"", "laser" and "computer" art.

B. Galeev described the activities of the design department as follows: "A series of the instruments of light 'Prometheus', 'Crystal', which are used to perform the works of A. Scriabin, N. RimskyKorsakov, I. Stravinsky and others; the first theatrical open-air light-performance 'Forever in the Memory of People' in the country; the first light and music films after the music of E. Varez, G.
Sviridov and others. There are several objects of the architecture of light in Kazan - "Crimson Ringing" in the Kremlin Spasskaya Tower, light and music stained-glass windows in the hotel "Tatarstan" and in the Kazan Aviation Institute Museum. Also, there is original dynamic lighting of the circus building where the change of color is no longer associated with sound, but with the state of the weather. Regular equipment has been designed to control powerful light and music fountains. The unique 24-channel 'spatial music' setup allows the sound to move in any direction in the space of the hall. Finally, there are many different light and music devices for interior decoration recreation rooms at industrial enterprises, crash course classes, aesthetic therapy rooms in medicine, control rooms for solving problems of engineering psychology, as well as discos, museums, theaters and clubs. The technical means involved are also diverse - from conventional overhead projections to cathode-ray tubes and liquid crystals. At one time, the apparatus 'Idel' and 'Yalkyn' were presented to the cosmonaut corps of the USSR, another version of the equipment - to the $15^{\text {th }}$ Congress of the Komsomol". Some of the equipment was put into mass production at one of the Kazan factories ... [Galeev, 1988, p. 31].

For many years B. Galeev dealt with theoretical problems concerning new types of art (light and music, electronic music, kinetic art, "Sound and Light" performances, etc.) and their practical implementation. Naturally, the researcher wanted to determine their place in the system of arts, as this territory was mainly occupied by traditional types of art (architecture, painting, sculpture, the art of words, music, ballet, theater). Rightly believing that the new system of arts is an "expanding" system, in which the emergence of new types is possible, B. Galeev jokingly called it, by analogy with Mendeleev's system, “The Galeev Periodic System of Arts".

B. Galeev first presented the principles of this system in his article "The Criterion of Artistry in the Systemic Forecasting of New Types of Art" [Galeev, 1984], [Galeev, 2002], written on the basis of a report at the conference of the Kazan base group in 1983.

B. Galeev's criteria for the functioning viability of new types of art in culture are based on $\mathrm{S}$. Eisenstein's concept of "Grundproblem". Speaking about the features characterizing figurative thinking, S. Eisenstein noted that figurative thinking includes a dual process: "a rapid progressive ascent along the line of higher levels of consciousness and 
simultaneous penetration through the structure of form into the layers of the deepest sensory thinking. The polar separation of these two lines of striving creates that wonderful tension of the unity of form and content that distinguishes genuine works of art" [Eisenstein, p. 120]. In this unity of the two components, the rational principle is the leading one, it controls the sensory component. The figurative-emotional component, with its metalogic and synesthetic nature, generates the intensity of the artistic impact that a work of art can exert.

In this article, B. Galeev uses the graphicstructural method for his system-type analysis of art, based on this criterion.

Initially, art is known to have been syncretic. Gradually, the artistic activity gets more specialized: man's essential powers are objectified in the form of autonomous arts (traditional types of arts, using "natural" means of communication). B. Galeev presents this system, which took shape by the Renaissance, in the form of the following scheme [Galiev, 1984, pp. 138-139]:

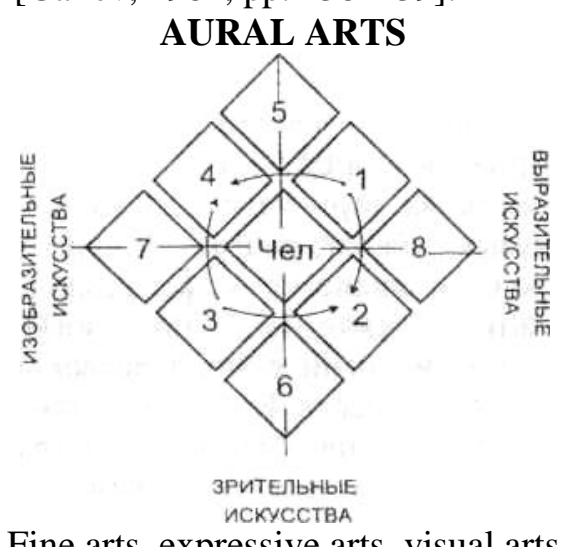

Fine arts, expressive arts, visual arts

where 1 is music, 2 - architecture, ornament, 3 painting, sculpture, 4 - the art of word, 5 - song art, 6 - applied arts, 7 - acting, 8 - theatrical art. There are different kinds of interactions between the components of this system (synthesis, interactions "at a distance"): e.g. in acting and dance, in song and applied arts, we find both centripetal and centrifugal forces.

New types of artistic activity, which have appeared due to the development of the "artificial" means of audiovisual communication, lead to the expansion of the art system, which now has a more complex structure, where 9 is electronic music; 10 - kinetic art; 11 - photography, cinematography; 12 - radio, theater; 13 - television; 14 - light and music; 15 - "spatial" music; 16 - "maze"; 17 "Sound and Light" performances; 18 - "Laterna magica"; 19, 10, 21 - aestheticization of the sound environment; 22, 23, 24 - aestheticization of the light environment [Ibid, p. 140].

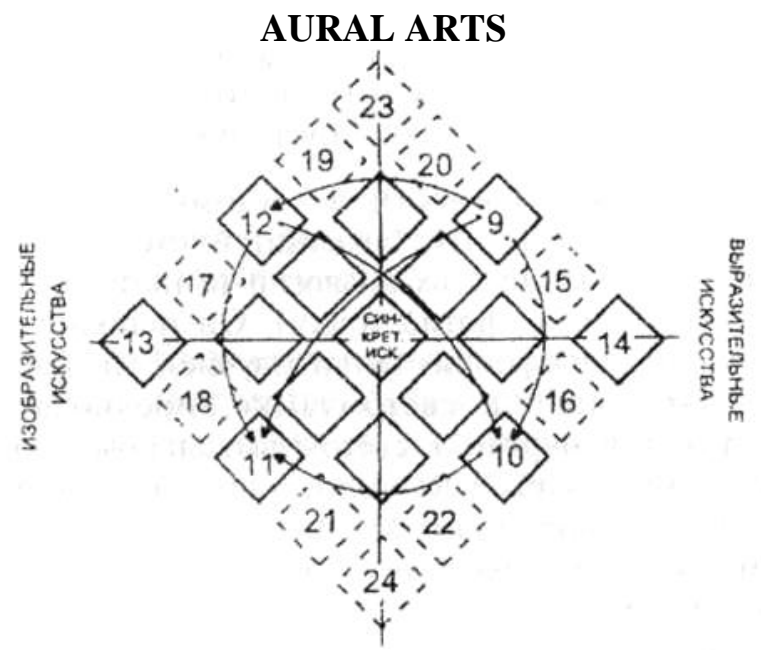

VISUAL ARTS

Most of the types identified here acquire vitality only due to the influence of intrasystemic connections that ensure the integrity of the art system.

In his research [Galeev, 2002], B. Galeev discusses many of the new types of art, but his main attention is focused on light and music, for the practical implementation of which the group of the "Prometheus" department designed and created a number of computer devices.

"Music of Light" ("visible music"), like traditional forms of art (music, dance), is the art of "intonated meaning", not an arbitrary manipulation of light and sound material.

The music of light represents an artistic synthesis of sound and light, which is based on a systemic principle: "The synthesis of sound and color should not be based on their mutual duplication," the researcher notes, "but on the use of a new quality arising from their joint impact. The quality that individually each of them, sound and color, does not possess" [Ibid, p. 51].

B. Galeev uses the following visual and auditory analogies: "the rhythm, dynamics of sound - the rhythm, dynamics of "the gesture of light", the melodic development - the graphic development, the timbre development - the color development of a graphic design, the tonality development - the color development of the entire visible picture, the movement along the registers - the change of the size and lightness of the visible" [Ibid, p. 139].

Like A. Scriabin and S. Eisenstein, B. Galeev believed that the criterion of artistry in light and music was the counterpoint relationship of these analogies (not their duplication; the counterpoint of letters, a point against a point). He used the musi- 
cological term "polyphony" (polyphonic), "polyphonic synthesis" in relation to the music of light, assuming that both the light and sound parts in a music-of-light work represent independent "voices", play their own melody, which in their synthesis leads to the emergence of a new meaning, a new quality. Thanks to this, the music of light can be considered an independent art form. Selfdeveloping "voices" must obey a single concept, as a result of which a light-musical work becomes an integrity unit, a system capable of selfdevelopment.

Light and music, as a temporary art, is performed on special light instruments as spatial art which can be filmed.

Considering various aspects of research into light and music, B. Galeev focused on the phenomenon of synesthesia, the psychological basis of light and music thinking. Arguing against a number of scientists, he proved that synesthesia is not a brain anomaly, a deviation from the norm, but a form of non-verbal thinking associated with intersensory comparisons and juxtapositions. Synesthesia is "one of the forms of interaction in the polysensory system of perception" [Ibid, p. 273]. This term means "co-representation", "co-feeling", by its psychological nature, it is an intersensual association (by contiguity, more often by similarity).

For art, the most characteristic types of synesthesia, notes B. M. Galeev, are the ones similar in emotional impact (timbre - color, tonality - coloring). Both higher and lower emotions are involved in the birth of synesthesia, as well as some mental operations at the subconscious level. Then synesthesia is fixed in a word or in a light-musical image. The researcher concludes: "Being a specific form of interaction in an integral system of sensory reflection, synesthesia is a manifestation of the human essential forces" [Ibid, p. 270].

In the monosensory arts, synesthesia has a compensatory function. In the works on light and music, it creates a psychological setting for the most expected juxtapositions of light and music. In an auditory-visual work, this "banal" attitude (B. Galeev) must be outdone by an aesthetic attitude, conditioned by a specific artistic intention. Synesthesia cannot be transferred straightforwardly to the figurative system of light-musical works.

The development of the music of light issues and synesthesia was associated with the work of A. Skryabin. Like B. Galeev, I. Vanechkina studied the idea of A. Skryabin's symphony of light for many years. She presented her research results in a voluminous monograph [Vanechkina, Galeev].
Then she expanded the interest in "color hearing" and created a special pedagogical technique assuming the fixation of synesthetic associations on canvas and on paper, and together with her student I. Trofimova (who defended her Ph.D. thesis on this topic) subsequently published a monograph on this technique [Vanechkina, Trofimova].

Having studied the genesis of the music of light (as the art of instrumental "gesture"), B. Galeev, also introduced this issue into the field of pedagogy and prepared a textbook for conservatory students, based on the previously published monograph [Galeev, 1976] [Galeev. Teatralizovannye ...]. Simultaneously, he studied the specificity of synesthesia as a special intersensory association that promotes the formation of special, synesthetic metaphors in poetry and other forms of art [Galeev, 1982].

The head of the "Prometeus" design department is the author of about 30 inventions, for which he received copyright certificates either individually or in co-authorship with his colleagues ${ }^{1}$.

From the 1970s, although deprived of the opportunity to participate in foreign exhibitions and film festivals, the researcher actively corresponded with foreign artists and composers such as Nicolas Schaeffer, Frank Malina, Janis Xenakis, Lev Theremin, etc. B. Galeev took part in the demonstration program of the All-Union Festival "Light and Music" (Kazan, 1987), the republican exhibition "New Art" (Kazan, 1993), international exhibitions and festivals (Electra-83, Paris), "Ars electronic-89" (St. Ling, Austria), WRO-89 (Wroclaw, Poland), Images du Futur-91 (Montreal), Impakt91 (Utrecht, Netherlands), Videoart-91 ( Locarno, Switzerland), "Asdemia of light-91" (The Hague, Netherlands), "Ostranenie-93" (-95, -97) (Dessau, Germany), "Videofenster-98" (St. Basel, Switzerland), "Oberhausen-2000" (Oberhasen, Germany), as well as a number of international symposia in Holland, Ireland, France and Austria.

B. Galeev was an organizer of research conferences and seminars on the problems of the music of light and synesthesia in his homeland ("New Technologies in Culture and Art", "Light and Music on Cinema and Television Screens", "Functional Light Music in Industry", "Medicine and Pedagogy, Electronics, Music, Light", "Light and Sound in Architecture", "Spatial Music: History, Theory, Practice", "Synesthesia: Commonwealth of Feelings and Synthesis of Arts", "Prometheus' $-2000 ")$.

\footnotetext{
${ }^{1}$ See:Appendix.
} 
Today, Kazan hosts conferences and readings dedicated to the memory of B. Galeev, which aim to popularize his ideas ([Galeevskie chteniia, 2010], [Galeevskie chteniia, 2012]. [Galeevskie chteniia, 2015], [Galeevskie chteniia, 2020].

"The Planet Galeev" is a collection of articles and memories devoted to the life and work of this scientist and artist. I. Vanechkina and N. Kolyadenko's articles, around which the memoirs of the former colleagues and disciples of B. Galeev are grouped, ensure the semantic integrity of the work. The collection includes research papers of the scientist, as well as his photos and archival photographs, shedding light on the genealogy of the scholar [Planeta Galeev].

To honor B. Galeev's 80th anniversary, the exhibition "Prometheus of the Space Age" (September 17, 2020) was opened in the Gallery of Contemporary Art at the Pushkin Museum of the RT. The exhibition features over 100 works of art - objects, models, films and other artifacts related to the activities of "Prometheus", as well as works by Konstantin Vasiliev, Nadir Almeev, Oleg Sokolov, Alexey Anikeenko and Vyacheslav Koleichuk who collaborated with B. Galeev. One of the main events of the exhibition was the reconstructed light-kinetic model of the monument, invented by the Soviet artist and inventor Grigory Gidoni in 1927 and recreated at the initiative of Bulat Galeev for the 1987 exposition entitled "A Monument to the Revolution by G. Gidoni". The exhibition was organized by the Prometheus Foundation for the Support of Audiovisual and Technological Art named after B. Galeev, which is headed by Anastasia Maksimova. This exhibition was also timed to coincide with the centenary of the TASSR.

The works of B. Galeev, the founder of the Kazan school of light and music, the researcher of the philosophical and aesthetic foundations of synesthesia, the pioneer of Russian video culture, remain relevant to this day. Over the years, scientists and experts have been displaying a growing interest in his works. The Galeev Readings have become a place of attraction for researchers of various fields from different parts of the world.

\section{References}

Eizenshtein, S. (1964-1971). Izbrannye sochineniia [Selected Works]. 6 t. T. 2. 593 p. Moscow. (In Russian)

Elektronika, muzyka, svet (1996) [Electronics, Music, and Light]. Materialy mezhdunar. nauch.-prakt. konf., Kazan', 10-14 dek. 1996 g. (K 100-letiiu so dnia rozhdeniia L. S. Termena). 299 p. Kazan', Fen. (In Russian)
Funktsional'naia svetomuzyka na proizvodstve, $v$ meditsine $i$ v pedagogike (1988) [Functional Light Music in Production, Medicine and Pedagogy]. Resp. nauch.-prakt. seminar, 22-24 okt. 1988 g. Tez. dokl. Kazan', KAI, 120 p. (In Russian)

Galeev, B. (1988). Svetit' vezde [To Shine Everywhere]. Ural'skii sledopyt. No. 8, pp. 31-33. (In Russian)

Galeev, B. (1991). Svetomuzyka v sisteme iskusstv [Music of Light in the System of Arts]. 86 p. Kazan', KGK. (In Russian)

Galeev, B. (1976). Svetomuzyka: stanovlenie $i$ sushchnost' novogo iskusstva [Music of Light: Formation and Essence of New Art]. 272 p. Kazan', Tatar. kn. izd-vo. (In Russian)

Galeev, B. (1982). Sodruzhestvo muz $i$ sintez iskusstv [The Commonwealth of Muses and Synthesis of Arts]. 63 p. Moscow, Znanie. (In Russian)

Galeev, B. M. (1985). Problema sinestezii $v$ iskusstve: filosofsko-esteticheskiy analiz: dis. ... dokt. filos. nauk [The Problem of Synesthesia in Art: Philosophical and Aesthetic Analysis: Doctoral Thesis]. Kazan', 384 p. (In Russian)

Galeev, B. M. (2020). Assalyamagaleykum, al'Barudi! [Assalamu alaykum, al-Barudi!]. Kazan'. 29 iiulia. URL: http://kazan-journal.ru/news/tassr100/assalyamagaleykum-al-barudi (accessed: 26.10.2020). (In Russian)

Galeev, B. M. (2002). Iskusstvo kosmicheskogo veka [Art of the Space Age.]. 571 p. Kazan', Fen, (In Russian)

Galeev, B. M. (1984). Kriterii khudozhestvennosti pri sistemnom prognozirovanii novykh vidov iskusstv [Criteria for Artistry in Systematic Forecasting of New Types in Arts]. Kriterii khudozhestvennosti v literature i iskusstve. Kazan', pp. 133-140. (In Russian)

Galeev, B. M. (1980). Poiushchaia raduga: Rasskazy o svetomuzyke i svetomuzykantakh [A Singing Rainbow: Stories about Music of Light and Musicians of Light]. 120 p. Kazan', Tatar. kn. izd-vo. (In Russian)

Galeev, B. M. (1978). Svetomuzykal'nye ustroistva [Light and Music Devices]. 176 p. Moscow, Energiia. (In Russian)

Galeev, B. M. (2010). Sovetskii Faust. Lev Termen - pioner elektronnogo iskusstva [Soviet Faust. Lev Theremin as a Pioneer of Electronic Art]. 178 p. Kazan', b. i.(In Russian)

Galeev, B. M. (1991). Teatralizovannye predstavleniia "Zvuk $i$ Svet" pod otkrytym nebom: ucheb. posobie [Theatrical Performances "Sound and Light" under an Open Sky: A Textbook]. 79 p. Kazan', KGK. (In Russian)

Galeev, B. M. (1973). Filosofskie problemy svetomuzykal'nogo sintezirovaniia kak formy otrazheniia deystvitel'nosti: dis. ... kand. filos. nauk [Philosophical Problems of Light-Music Synthesizing as a Form of Reflecting Reality: Ph.D. Thesis]. Kazan', 200 p. (In Russian)

Galeev, B. M., Andreev, S. A. (1973). Printsipy konstruirovaniia svetomuzykal'nykh ustroistv [Principles 
of Designing Light-Music Devices]. 102 p. Moscow, Energiia. (In Russian)

Galeev, B. M., Zorin, S. M., Saifullin, R. F. (1987). Svetomuzykal'nye instrumenty [Light-Musical Instruments]. 123 p. Moscow, Radio i svyaz'. (In Russian)

Galeyevskiye chteniia (2015) [The Galeev Readings]. Kazan'.

Galeevskie chteniia. Ot sinestezii k sintezu iskusstv ("Prometei"-2015) (2015) [The Galeev Readings]. (K 75-letiiu so dnia rozhdeniia B. M. Galeeva): materialy Mezhdunarodnoi nauchno-prakticheskoi konferentsii, Kazan', 2-4 oktyabria 2015 goda / Moskovskii gos. un-t im. M. V. Lomonosova, Filosofskii fak., kaf. estetiki, Kazanskiy nats. issled. tekhnicheskii un-t im. A. N. Tupoleva (KNITU-KAI), Upr. kul'tury ispolkoma g. Kazani, Tvorcheskoe ob-nie "Prometey". 387 p. Kazan', Brig. (In Russian)

Galeevskie chteniia (2020; Kazan'). [The Galeev Readings]. URL: https://us02web.zoom.us/j/ 7526538739? pwd=QVNKMEx6Q3o4TDE0K01yV

GlaRWpTdz09 (accessed: 26.10.2020). (In Russian)

Galeevskie chteniia (2010) [The Galeev Readings]. Materialy Mezhdunarodnoi nauchno-prakticheskoi konferentsii ("Prometey"-2010), Kazan', 2-6 oktiabria 2010 goda. 370 p. Kazan', izd-vo Kazanskogo gos. tekhnicheskogo un-ta. (In Russian)

Galeevskie chteniia (2012) [The Galeev Readings]. materialy Mezhdunarodnoy nauchno-prakticheskoy konferentsii ("Prometey"-2012), Kazan', 6-8 aprelia 2012 goda. 493 p. Kazan', izd-vo Kazanskogo gos. tekhnicheskogo un-ta. (In Russian)

Nigmatullina, Yu. G. (1980). Problema kompleksnosti izucheniia khudozhestvennogo tvorchestva [The Comprehensiveness Problem in the Studies of Artistic Creativity]. 174 p. Kazan', Kazan. un-t. (In Russian)

Nigmatullina, Yu. G. (2004). Sistemno-kompleksnoe issledovanie khudozhestvennogo tvorchestva: istoriia nauchnogo napravleniia $v$ Kazanskom universitete [System-Complex Research of Artistic Creativity: the History of the Scientific Trend at Kazan University]. 250 p. Kazan', Kazan. un-t. (In Russian)

Nigmatullina, Yu. G. (1992). Sistemnyi analiz khudozhestvennogo proizvedeniia [Systemic Analysis of a Work of Art]. Uchebno-metodicheskoe posobie. 158 p. Kazan', Kazan. un-t. (In Russian)

Novye tekhnologii v kul'ture i iskusstve (1995) [New Technologies in Culture and Art]. Region. nauch.-prakt. seminar, 6-7 iunia 1995 g., tez. dokl. 145 p. Kazan', NII "Prometey". (In Russian)

Planeta Galeev: stat'i, vospominaniia, dokumenty (2010) [Planet Galeev: Articles, Memoirs, Documents]. 418 p. Kazan', Kazanskaia gos. Konservatoriia. (In Russian)

"Prometei" - 2000: (O sud'be svetomuzyki: na rubezhe vekov) ["Prometheus" - 2000: (On the Fate of Light and Music: At the Turn of the Century)]. Materialy Mezhdunar. nauch.-prakt. konf., Kazan', 2-6 okt. 2000 g. 263 p. Kazan', Fen. (In Russian)
Prostranstvennaia muzyka: istoriia, teoriya, praktika (2004) [Spatial Music: History, Theory, Practice]. Akad. nauk resp. Tatarstan, Kazan. gos. tekhn. un$\mathrm{t}$ im. A. N. Tupoleva, NII eksperim. estetiki "Prometey". 158 p. Kazan', Fen. (In Russian)

Russkoie literaturovedenie $v$ Kazanskom universitete (1806-2009) (2011) [Russian Literary Studies at Kazan University]. Bibliograficheskii slovar' / sost.: L. Ya. Voronova, M. M. Sidorova; nauch. red. L. Ya. Voronova. 229 p. Kazan', Kazan. un-t. (In Russian)

Saiapova, A. M. (2014). Glava kazanskoi shkoly sistemno-kompleksnogo issledovaniia khudozhestvennogo tvorchestva [Head of Kazan School of System and Comprehensive Research on Artistic Works]. Filologiia i kul'tura. Philology and Culnure. No. 2(36), pp. 327-330. (In Russian)

Svet $i$ zvuk $v$ arkhitekture (1990) [Light and Sound in Architecture]. Nauch.-prakt. seminar, 27-29 okt.: tez. dokl. Kazan', KAI, 127 p. (In Russian)

Svetomuzyka na kino- i teleekrane (1989) [Light and Music on Cinema and Television Screens]. Nauch.prakt. seminar: tez. dokl., 28-30 okt. 1989 g. Kazan', KAI, 88 p. (In Russian)

Sinesteziia: sodruzhestvo chuvstv $i$ sintez iskusstv (2008) [Synesthesia: Commonwealth of Senses and Synthesis of Arts]. Materialy Mezhdunarodnoi nauchnoprakticheskoi konferentsii. Kazan', 3-8 noiabria 2008 g. Akad. nauk Tatarstana, Upravlenie kul'tury ispolkoma g. Kazani, Kazanskii gos. tekhnicheskii un-t im. A. N. Tupoleva, Kazanskaia gos. konservatoriia, NII eksperimental'noi estetiki "Prometei”. 360 p. Kazan', izd-vo KGTU im. A. N. Tupoleva. (In Russian)

Sintsov, Ye. V. (1995). Dialektika voploshchaemogo $i$ vozmozhnogo $v$ myslitel'nykh protsessakh: $\mathrm{Na}$ materiale tvorchestva $v$ iskusstve: dis. ... dokt. filos. nauk [Dialectics of the Embodied and the Possible in the Thinking Processes: Based on Creativity in Art: Doctoral Thesis]. Iekaterinburg, 381 p. (In Russian)

Sintsova, S. V. (2000). Khudozhestvennoe predvidenie morfologicheskikh novoobrazovanii iskusstva sredstvami slovesnogo iskusstva: avtoref. dis. ... kand. filos. nauk [Artistic Foresight of Morphological Neoformations in Art by Means of Verbal Art: Ph.D. Thesis]. NII eksperimental'noi estetiki "Prometei". Yekaterinburg, 19 p. (In Russian)

Vanechkina, I., Galeev, B. (1981). Poema ognia (kontseptsiia svetomuzykal'nogo sinteza A. N. Skriabina) [The Poem of Fire (the concept of lightmusic synthesis by A. N. Scriabin)]. 168 p. Kazan', izdvo KGU. (In Russian)

Vanechkina, I., Trofimova, I. (2000). Deti risuiut muzyku [Children Draw Music]. 119 p. Kazan', Fen. (In Russian)

\section{Appendix}

Pat. 1324673 Rossiiskaia Federatsiia, MPK A63J17/00. Formoobrazuiushchii svetootrazhatel' [A Light Reflector Shaper]. B. M. Galeev, E.V. Gorbunova, P. G. Artem'iev. - 3967021/24-21, zaiavl. 21.10.1985; opubl. 23.07.1987. 
Pat. 1017355 Rossiiskaia Federatsiia, MPK A63J 17/00. Tsvetomuzykal'nyi instrument [A Color Musical Instrument]. B. M. Galeev - 3314035, zaiavl. 07.08. 1981; opubl. 05.15. 1983.

Pat. 919693 Rossiiskaia Federatsiia, MPK A63J17/00. Svetomuzykal'noie ustroistva [Light and Music Devices]. V. P. Bukatin, B.M. Galeev. 2897072/ 28-21, zaiavl. 23. 03. 1980; opubl. 15.04.1982.

Pat. 1351617 Rossiiskaia Federatsiia, MPK A63J17/00. Kasseta dlia formoobrazovatelei svetomuzykal'nogo ustroistva [Cassette for Shapers of Light and Music Devices]. V. P. Bukatin, B. M. Galeev i Saifullin R. F. - 3901127, zaiavl. 27.05.1985; opubl. 15.11.1987.

Pat. 862961 Rossiiskaia Federatsiia, MPK A63J17/00. Svetomuzykal'noe ustroistvo [A Light and Music Device]. V. G. Boldin, V. P. Bukatin i B. M. Galeev- 2854805/18-21, zaiavl. 17.12.79; opubl. 15.09.81.

Pat. 1331526 Rossiiskaia Federatsiia, MPK A63J17/00. Vykhodnoe opticheskoe ustroistvo svetomuzykal'noi ustanovki [An Output Optical Device of the Light and Music Apparatus]. B. M. Galeev 3769744/24-12, zaiavl. 05.07.84, opubl. 23.08.87.

Pat. 1351618 Rossiiskaia Federatsiia, MPK A63J17/00. Formirovatel' upravliaiushchikh signalov dlia svetomuzykal'nogo ustroistva [A Shaper of Control
Signals for a Light and Music Device]. V. P. Bukatin, B. M. Galeev i R. F. Saifullin - 3901127 A1, zaiavl. 27.05.85; opubl. 15.11.87.

Pat. 1365023 Ustroistvo dlia sozdaniia svetovykh effektov [A Device for Creating Light Effects]. B. M. Galeev - 4101126/ 31-10, zaiav. 30.07.86.; opubl. 07.01.88.

Pat. 1448167 Vykhodnoe opticheskoe ustroistvo svetodinamicheskoi ustanovki [Output Optical Device of a Dynamic Light Setup]. B. M. Galeev - 4274269/3112, zaiavl. 20.05.87; opubl. 30.12.88.

Pat. $1540844 \quad$ Elektronnyi sintezator svetomuzykal'nykh izobrazhenii na tsvetnoi elektronnoluchevoi trubke [Electronic Synthesizer of Light and Music Images on a Color Cathode-Ray Tube]. V. P. Bukatin, B. M. Galeev, Ye. V. Gorbunova i R. F. Saifullin - 4226494, zaiavl. 9.04.87, opubl. 07.02.90.

Pat. 1569027 Svetomuzykal'noe ustroistvo [A Light and Music Device]. B. M. Galeev, V. P. Bukatin 4460402/24-21, zaiavl. 9.04.87, opubl. 07.02.90.

Pat. 17005231 Svetomuzykal'nye ustroistva [Light and Music Devices]. Moscow, Energiia, 1978. Pp.131134. B. M. Galeev, R. F. Saifullin. - 3754436/10

Pat. 1719004. Vykhodnoe opticheskoe ustroistvo svetomuzykal'noi ustanovki [An Output Optical Device of the Light and Music Apparatus]. B. M. Galeev 4810741/12, zaiavl. 09.04.90; 15.03.92.

\title{
ВКЛАД БУЛАТА ГАЛЕЕВА В КОМПЛЕКСНОЕ ИЗУЧЕНИЕ ХУДОЖЕСТВЕННОГО ТВОРЧЕСТВА
}

\author{
Юлдуз Галимзяновна Нигматуллина, \\ Казанский федеральный университет, \\ Россия, 420008, г. Казань, ул. Кремлевская, д. 18, \\ ermakeev@mail.ru.
}

\begin{abstract}
В статье очерчен вклад Булата Махмудовича Галеева в развитие межвузовского научного направления, возникшего на филологическом факультете Казанского университета в 19701980-е гг., когда специалисты разного профиля объединились для реализации системнокомплексного подхода в исследовании явлений литературы и искусства. В работе дается краткая характеристика научной концепции Б. М. Галеева, руководителя СКБ «Прометей», занимавшегося историей и теорией светового искусства в Татарстане, подведены итоги его многолетней работы.
\end{abstract}

Ключевые слова: системно-комплексное изучение литературы и искусства, Казанский университет, Ю. Г. Нигматуллина, Б. М. Галеев, СБК «Прометей», теория светомузыки.

Характерной чертой науки 1960-70-х гг. являлось стремление к объединению разных дисциплин при исследовании фундаментальных проблем науки. В гуманитарных науках также возникла потребность комплексного исследования литературы и искусства. С этой целью в середине 1960-х гг. была организована постоянная Комиссия комплексного изучения худо- жественного творчества при Научном совете по истории мировой культуры АН СССР во главе с профессором Б. С. Мейлахом. В апреле 1979 г. при Казанском университете была организована и утверждена Казанская базовая группа Комиссии АН СССР (председатель координационного совета - доктор филологических наук, профессор Ю. Г. Нигматуллина). В группу 
вошли научные работники, преподаватели, аспиранты КГУ, Казанского филиала АН СССР, КАИ (СКБ «Прометей»), КГПИ, Института культуры, а также писатели и критики (всего около 40 человек) (см. подр.: [Нигматуллина, 1980], [Нигматуллина, 1992], [Нигматуллина, 2004], [Русское литературоведение в Казанском университете (1806-2009)], [Саяпова]).

Группой СКБ «Прометей» в КАИ руководил Булат Махмудович Галеев (1940-2009), правнук основоположника казанского медресе «Мухамадия», племянник Г. Баруди, первого ректора этого медресе [Галеев, 2020]. Единомышленники и друзья вспоминают о Б. М. Галееве как об очень организованном, ответственном, отзывчивом человеке. Перечень его достижений весьма внушительный, и это свидетельствует о том, что ученый был уникальным человеком. В 1973 г. он защитил кандидатскую диссертацию «Философские проблемы светомузыкального синтезирования как формы отражения действительности» [Галеев, 1973]. Итогом многолетних исследований стала защита докторской диссертации «Проблема синестезии в искусстве: философско-эстетический анализ» [Галеев, 1985]. Б. М. Галеев является автором многих книг ([Галеев, Андреев], [Галеев, 1976], [Галеев, 1978], [Галеев, 1980], [Ванечкина, Галеев], [Галеев, 1982], [Галеев, Зорин, Сайфуллин], [Галеев, 2002], [Галеев, 2010]), учебных пособий ([Галеев. Светомузыка...], [Галеев. Театрализованные...]) и более пятисот статей по современному искусству в отечественных и зарубежных изданиях.

Под руководством Б. М. Галеева работало 10-15 человек. С 1993 года, когда был организован НИИ, комплексное исследование на стыках «искусство - наука - техника» начало осуществляться уже в официально-плановом порядке, а не «на общественных началах». Появилась возможность интенсификации исследований по истории и теории светового искусства в Татарстане. Интересны продуктивные поиски следов комплексности в истории казанской науки прошедших лет начиная с рубежа XIX$\mathrm{XX}$ вв. (ими занималась Е. Ключевская и др.). Сам Б. М. Галеев продолжал изучать синестетические метафоры в русской и зарубежной поэзии. Перспективными оказались результаты изучения особенностей прогнозирования средствами самого искусства (С. Синцова защитила по данной теме кандидатскую диссертацию [Синцова]). Е. Синцов, вышедший из недр литературоведческой группы комплексного изу- чения творчества, пришедший в коллектив на правах совместителя, подключился к исследованию синестетической аналогии «музыка орнамент», издал монографию по этой теме [Синцов]. Параллельно группой инженеров и студентов была разработана аппаратура для преобразования визуальных, орнаментальных структур в мелодические (В. Скороходов и др.). Изучались художественные особенности и технология таких музыкальных новообразований, как «пространственная музыка», «лазерное» и «компьютерное» искусство.

Б. М. Галеев так охарактеризовал деятельность СКБ: «Серия светоинструментов „Прометей““, „Кристалл“, на которых исполнялись произведения А. Н. Скрябина, Н. А. РимскогоКорсакова, И. Ф. Стравинского и др. Первое в стране театрализованное свето-представление под открытым небом „Навечно в памяти народной“. Первые светомузыкальные фильмы на музыку Э. Вареза, Г. В. Свиридова и др. В Казани действуют несколько объектов световой архитектуры - „Малиновый звон“" в Спасской башне кремля, светомузыкальные витражи в гостинице „Татарстан“, в музее КАИ. Оригинальна динамическая подсветка здания цирка, где изменения цвета были связаны уже не со звуком, а с состоянием погоды. Сконструирована типовая аппаратура для управления мощными светомузыкальными фонтанами. Уникальна 24-канальная установка ,пространственной музыки“, позволяющая звуку двигаться по любой траектории в объеме зала. И, наконец, множество различных светомузыкальных приборов для оформления интерьеров - кабинетов релаксации на производстве, классов интенсивного обучения, залов эстетотерапии в медицине, пультовых помещений при решении задач инженерной психологии, а также дискотек, музеев, театров, клубов. Многообразны и привлекаемые технические средства - от обычной диапроекции до электронно-лучевой трубки и Жидких кристаллов. Установки „Идель“, „Ялкын“ были подарены в свое время отряду космонавтов ССCР, другой вариант - XV съезду ВЛКСМ». Часть аппаратуры была запущена в серийное производство одним из казанских заводов... [Галеев, 1988, с. 31].

Б. М. Галеев в течение многих лет занимался теоретическими проблемами новых видов искусства (светомузыки, электронной музыки, кинетического искусства, представлений «Звук и Свет» и др.) и их практического воплощения. Естественно, что у исследователя возникло же- 
лание определить их место в системе искусств, территорию которой в основном занимали традиционные виды искусства (архитектура, живопись, скульптура, искусство слова, музыка, балет, театр). Справедливо полагая, что новая система искусств является «расширяющейся» системой, в которой возможно появление новых видов, Б. М. Галеев шутливо назвал ее, по аналогии с менделеевской системой, «периодической системой искусств Б. М. Галеева».

Изложение принципов, на которых основана эта система, впервые было дано Б. М. Галеевым в статье «Критерий художественности при системном прогнозировании новых видов искусства» [Галеев, 1984], [Галеев, 2002], написанной на материале доклада, прочитанного на конференции Казанской базовой группы в 1983 году.

При определении критериев жизнеспособности функционирования новых видов искусства в культуре Б. М. Галеев опирается на концепцию С. Эйзенштейна «Grundproblem». Говоря о специфике образного мышления, С. Эйзенштейн отмечал, что в нем, образном мышлении, происходит двойственный процесс: «стремительное прогрессивное вознесение по линии высших ступеней сознания и одновременно же проникновение через строение формы в слои самого глубинного чувственного мышления. Полярное разведение этих двух линий устремления создает ту замечательную напряженность единства формы и содержания, которая отличает подлинные произведения» [Эйзенштейн, с. 120] В этом единстве двух компонентов рациональное начало является ведущим, оно управляет чувственным компонентом. Образно-эмоциональный компонент, с его металогичностью и синестетичностью, обеспечивает силу художественного воздействия произведения искусства.

На этом критерии в статье Б. М. Галеева базируется системновидовой анализ искусства, в основу которого был положен графическиструктурный метод.

Изначально искусство, как известно, было синкретическим. Постепенно происходит специализация художественной деятельности: сущностные силы человека опредмечиваются в виде автономных искусств (традиционных видов искусств, использующих «натуральные» средства коммуникации). Эта система, сложившаяся к эпохе Возрождения, представлена Б. М. Галеевым в виде следующей схемы [Галиев, 1984, с. 138-139]:

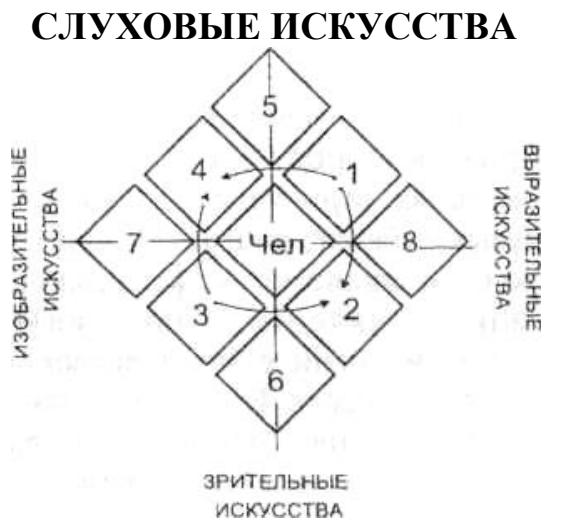

где 1 - музыка, 2 - архитектура, орнамент, 3 живопись, скульптура, 4 искусство слова, 5 песенное искусство, 6 - прикладное, 7 - актерское, 8 - театральное. Между компонентами этой системы существуют взаимодействия разного рода (синтез, взаимодействия «на расстоянии»): например, в актерском и танцевальном искусстве, песенном и прикладном действуют как центростремительные, так и центробежные силы.

Новые виды художественной деятельности, рожденные при освоении «искусственных» средств аудиовизуальной коммуникации, приводят к расширению системы искусства, которая теперь имеет более сложную структуру, где 9 - электронная музыка; 10 - кинетическое искусство; 11 - фотография, кинематограф; 12 радиотеатр; 13 - телевидение; 14 - светомузыка; 15 - «пространственная» музыка; 16 «лабиринт»; 17 - представления «Звук и Свет»; 18 - «латерна магика»; 19, 10, 21 - эстетизация звуковой среды; 22, 23, 24 - эстетизация световой среды [Там же, с. 140].

\section{СЛУХОВЫЕ ИСКУССТВА}

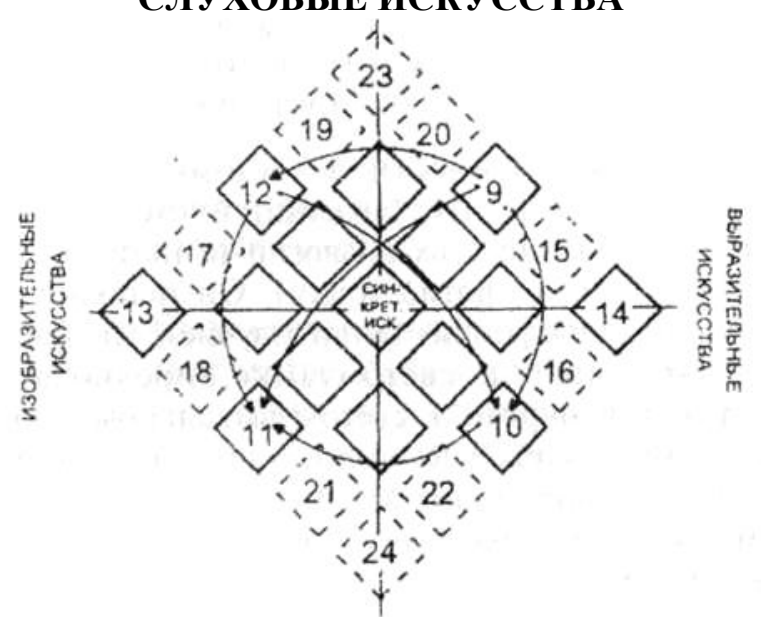

ЗРИТЕЛЬНЫЕ ИСКУССТВА 
Большинство из выделенных здесь видов обретают жизнеспособность лишь под воздействием внутрисистемных связей, обеспечивающих целостность системы искусства.

В своих исследованиях [Галеев, 2002] Б. М. Галеев касается многих из новых видов искусства, но основное внимание его сосредоточено на светомузыке, для практического воспроизведения которой группа СКБ «Прометей» спроектировала и создала ряд компьютерных устройств.

«Светомузыка» («видимая музыка»), как и традиционные виды искусства (музыка, танец), является искусством «интонируемого смысла», а не произвольным манипулированием световым и звуковым материалом.

Светомузыка представляет художественный синтез звука и света, в основе которого лежит системный принцип: «Синтез звука и цвета должен быть основан не на их взаимном дублировании, - отмечает исследователь, - но на использовании нового качества, возникающего при их совместном воздействии. Качества, которым каждый из них в отдельности - звук и цвет - не обладает» [Там же, с. 51].

Б. М. Галеев приводит следующие визуальные и слуховые аналогии: «ритм, динамика звука - ритм, динамика „светового жеста“, мелодическое развитие - графическое развитие, тембровое развитие - цветовое развитие графического рисунка, тональностное развитие цветовое развитие всей видимой картины, движение по регистрам - изменение размера и светлоты видимого» [Там же, с. 139].

Критерием художественности в светомузыке Б. М. Галеев вслед за А. Н. Скрябиным и С. Эйзенштейном считает контрапунктическое соотношение этих аналогий (а не их дублирование; контрапункт букв, точка против точки). Он использует музыковедческий термин «полифония» (многозвучие), «полифонический синтез» применительно к светомузыке, предполагая, что и световая, и звуковая партии в светомузыкальном произведении представляют самостоятельные «голоса», играют свою мелодию, что в синтезе приводит к появлению нового смысла, нового качества. Именно благодаря этому светомузыка может считаться самостоятельным видом искусства. Самостоятельно развивающиеся «голоса» должны подчиняться единому замыслу, вследствие чего светомузыкальное произведение становится целостностью, системой, способной к саморазвитию.
Светомузыка, как временное искусство, исполняется на специальных световых инструментах, как пространственное искусство, может быть запечатленной на пленку.

Рассматривая разные аспекты изучения светомузыки, Б. М. Галеев останавливается на феномене синестезии - психологической основы светомузыкального мышления. Полемизируя с рядом ученых, он доказывает, что синестезия не является аномалией мозга, отклонением от нормы, а формой невербального мышления, связанного с межчувственными сопоставлениями и сравнениями. Синестезия - «одна из форм взаимодействия в полисенсорной системе восприятия» [Там же, с. 273]. Этот термин означает «со-представление», «со-чувствование», по психологической природе - это межчувственная ассоциация (по смежности, чаще - по сходству).

Наиболее присущ искусству, отмечает Б. М. Галеев, тип синестезий, сходных по эмоциональному воздействию (тембр - цвет, тональность - колорит). В рождении синестезии участвуют и высшие, и низшие эмоции, а также и некоторые мыслительные операции на подсознательном уровне. Затем синестезия фиксируется в слове или в светомузыкальном образе. Исследователь делает вывод: «Будучи специфической формой взаимодействия в целостной системе чувственного отражения, синестезия есть проявление сущностных сил человека» [Там же, с. 270].

В моносенсорных искусствах синестезия выполняет компенсаторскую функцию. В светомузыкальных произведениях она создает психологическую установку на наиболее ожидаемые сопоставления света и музыки. Эта «банальная» установка (Б. Галеев) должна преодолеваться (в слухозрительном произведении) эстетической установкой, обусловленной конкретным художественным замыслом. Нельзя прямолинейно переносить синестезию на образную систему светомузыкального произведения.

Разработка проблем светомузыки и синестезии была связана с обращением к творчеству Скрябина. И. Л. Ванечкина, как и Б. М. Галеев, много лет занималась изучением идеи световой симфонии Скрябина. Итоги своих изысканий она изложила в объемной монографии [Ванечкина, Галеев]. Затем она развернула сопутствующий этим изысканиям интерес к «цветному слуху» в особую педагогическую методику, связанную с фиксацией синестетических ассо- 
циаций на полотне, на бумаге, и вместе со своей ученицей И. Трофимовой (защитившей по данной теме кандидатскую диссертацию) опубликовала впоследствии монографию, посвященную этой методике [Ванечкина, Трофимова].

Б. Галеев, изучив генезис светомузыки (как искусства инструментального «жеста»), тоже вывел проблему в область педагогики, подготовив на основе ранее изданной монографии [Галеев, 1976] учебное пособие для студентов консерватории [Галеев. Театрализованные...]. Параллельно им изучалась специфика синестезии как особой межчувственной ассоциации, способствующей формированию особых, синестетических метафор в поэзии и других видах искусства [Галеев, 1982].

Руководитель СКБ «Прометей» является автором около 30 изобретений, за которые получил авторские свидетельства единолично или в соавторстве с коллегами ${ }^{1}$.

С 1970-х гг. исследователь, хотя и был лишен возможности участвовать в зарубежных выставках и кинофестивалях, активно переписывался с зарубежными художниками и композиторами, такими как Николя Шеффер, Франк Малина, Янис Ксенакис, Лев Термен и др. Галиев был участником демонстрационной программы Всесоюзного фестиваля «Свет и музыка» (Казань, 1987), республиканской выставки «Новое искусство» (Казань, 1993), международных выставок и фестивалей (Электра-83, Париж), «Ars electronic- 89» (г. Линг, Австрия), «WRO-89» (г. Вроцлав, Польша), «Images du Futur-91» (г. Монреаль), «Impakt-91» (г. Утрехт, Нидерланды), «Videoart-91» (г. Локарно, Швейцария), «Academia of light-91» (г. Гаага, Нидерланды), «Ostranenie-93» (-95, -97) (г. Дессау, Германия), «Videofenster-98» (г. Базель, Швейцария), «Oberhausen-2000» (г. Оберхазен, Германия), а также ряда международных симпозиумов в Голландии, Ирландии, Франции, Австрии.

Б. М. Галеев - организатор научных конференций и семинаров по проблемам светомузыки и синестезии у себя на родине ([Новые технологии в культуре и искусстве], [Светомузыка на кино- и телеэкране], [Функциональная светомузыка на производстве, в медицине и в педагогике], [Электроника, музыка, свет], [Свет и звук в архитектуре], [Пространственная музыка: история, теория, практика], [Синестезия:

\footnotetext{
${ }^{1}$ См.: Приложение.
}

содружество чувств и синтез искусств], [«Прометей»-2000].

В Казани проводится конференция, посвященная памяти Б. М. Галеева, и чтения, нацеленные на популяризацию его идей ([Галеевские чтения, 2010], [Галеевские чтения, 2012]. [Галеевские чтения, 2015], [Галеевские чтения, 2020].

«Планета Галеев» - сборник статей, воспоминаний о жизни и творчестве ученого и художника. Смысловая цельность работы достигается благодаря статьям И. Л. Ванечкиной и Н. П. Коляденко, вокруг которых группируются воспоминания коллег, учеников Б. М. Галеева. В сборник включены научные работы ученого, а также его фотоработы, архивные фотографии, проливающие свет на родословную ученого [Планета Галеев].

В честь 80-летия Б. М. Галеева в Галерее современного искусства ГМИИ РТ открылась выставка «Прометей космического века» (17 сентября 2020 г.). На выставке экспонируется свыше 100 произведений искусства - объектов, макетов, фильмов и других артефактов, связанных с деятельностью «Прометея», а также работы Константина Васильева, Надира Альмеева, Олега Соколова, Алексея Аникеенка и Вячеслава Колейчука, которые в разное время сотрудничали с Б. М. Галеевым. Одним из главных событий выставки стал реконструированный светокинетический макет памятника, придуманный советским художником и изобретателем Григорием Гидони в 1927 году и воссозданный по инициативе Булата Галеева для экспозиции 1987 года под названием «Памятник революции Г. Гидони». Выставка организована Фондом поддержки аудиовизуального и технологического искусства «Прометей» имени Б. М. Галеева, директором которого является Анастасия Максимова. Эта выставка приурочена также к 100-летию ТАССР.

Труды ученого Б. М. Галеева, основоположника казанской школы светомузыки, исследователя философско-эстетических основ синестезии, пионера отечественной видеокультуры, сохраняют актуальность и поныне, интерес к его работам растет среди ученых и специалистов год от года. «Галеевские чтения» стали местом притяжения исследователей самых разных областей из разных уголков мира.

\section{Литература}

Ванечкина И., Галеев Б. Поэма огня (концепция светомузыкального синтеза А. Н. Скрябина). Казань: изд-во КГУ, 1981. 168 с. 
Ванечкина И., Трофимова И. Дети рисуют музыку. Казань: Фэн, 2000. 119 с.

Галеев Б. Светить везде // Уральский следопыт. 1988. № 8. C. 31-33.

Галеев Б. Светомузыка в системе искусств. Казань: КГК, 1991. 86 с.

Галеев Б. Светомузыка: становление и сущность нового искусства. Казань: Татар. кн. изд-во, 1976. $272 \mathrm{c.}$

Галеев Б. Содружество муз и синтез искусств. М.: Знание, 1982. 63 с.

Галеев Б. М. Проблема синестезии в искусстве: философско-эстетический анализ: дис. ... докт. филос. наук. Казань, 1985. 384 с.

Галеев Б. М. Ассалямагалейкум, аль-Баруди! // Казань. 2020. 29 июля. URL: http://kazanjournal.ru/news/tassr-100/assalyamagaleykum-al-barudi (дата обращения: 26.10.2020).

Галеев Б. М. Искусство космического века. Казань: Фэн, $2002.571 \mathrm{c.}$

Галеев Б. М. Критерии художественности при системном прогнозировании новых видов искусств // Критерии художественности в литературе и искусстве. Казань, 1984. С. 133-140.

Галеев Б. М. Поющая радуга: Рассказы о светомузыке и светомузыкантах. Казань: Татар. кн. издво, $1980.120 \mathrm{c}$.

Галеев Б. М. Светомузыкальные устройства. Москва: Энергия, 1978. 176 с.

Галеев Б. М. Советский Фауст. Лев Термен пионер электронного искусства. Казань: б. и., 2010. $178 \mathrm{c}$.

Галеев Б. М. Театрализованные представления «Звук и Свет» под открытым небом: учеб. пособие. Казань: КГК, 1991. 79 с.

Галеев Б. М. Философские проблемы светомузыкального синтезирования как формы отражения действительности: дис. ... канд. филос. наук. Казань, 1973. $200 \mathrm{c}$.

Галеев Б. М., Андреев С. А. Принципы конструирования светомузыкальных устройств. Москва: Энергия, 1973. $102 \mathrm{c.}$

Галеев Б. М., Зорин С. М., Сайфуллин Р. Ф. Светомузыкальные инструменты. М.: Радио и связь, 1987.123 c.

Галеевские чтения (2015; Казань). Галеевские чтения. От синестезии к синтезу искусств («Прометей»-2015): (к 75-летию со дня рождения Б. М. Галеева): материалы Международной научно-практической конференции, Казань, 2-4 октября 2015 года / Московский гос. ун-т им. М. В. Ломоносова, Философский фак., каф. эстетики, Казанский нац. исслед. технический ун-т им. А. Н. Туполева (КНИТУКАИ), Упр. культуры исполкома г. Казани, Творческое об-ние «Прометей». Казань: Бриг, 2015. 387 с.

Галеевские чтения (2020; Казань). URL: https://us02web.zoom.us/j/7526538739?pwd=QVNKM Ex6Q3o4TDE0K01yV GlaRWpTdz09 (дата обращения: 26.10.2020).
Галеевские чтения: материалы Международной научно-практической конференции («Прометей»2010), Казань, 2-6 октября 2010 года. Казань: изд-во Казанского гос. технического ун-та, 2010. 370 с.

Галеевские чтения: материалы Международной научно-практической конференции («Прометей»2012), Казань, 6-8 апреля 2012 года. Казань: изд-во Казанского гос. технического ун-та, 2012. 493 с.

Нигматуллина Ю. Г. Проблема комплексности изучения художественного творчества. Казань: Казан. ун-т, 1980. 174 с.

Нигматуллина Ю. Г. Системно-комплексное исследование художественного творчества: история научного направления в Казанском университете. Казань: Казан. ун-т, 2004. 250 с.

Нигматуллина Ю. Г. Системный анализ художественного произведения / учебно-методическое пособие. Казань: Казан. ун-т, 1992. 158 с.

Новые технологии в культуре и искусстве: Регион. науч.-практ. семинар, 6-7 июня 1995 г.: тез. докл. Казань: НИИ «Прометей», 1995. 145 с.

Планета Галеев: статьи, воспоминания, документы. Казань: Казанская гос. консерватория, 2010. $418 \mathrm{c}$.

«Прометей» - 2000: (О судьбе светомузыки: на рубеже веков): Материалы Междунар. науч.-практ. конф., Казань, 2-6 окт. 2000 г. Казань: Фэн, 2000. $263 \mathrm{c}$.

Пространственная музыка: история, теория, практика / Акад. наук Респ. Татарстан, Казан. гос. техн. ун-т им. А. Н. Туполева, НИИ эксперим. эстетики «Прометей». Казань: Фэн, 2004. 158 с.

Русское литературоведение в Казанском университете (1806-2009). Библиографический словарь / сост.: Л. Я. Воронова, М. М. Сидорова; науч. ред. Л. Я. Воронова. Казань: Казан. ун-т, 2011. 229 с.

Саяпова A. М. Глава казанской школы системнокомплексного исследования художественного творчества. // Филология и культура. Philology and Culnure. 2014. 2(36). C. 327-330.

Свет и звук в архитектуре: Науч.-практ. семинар, 27-29 окт.: тез. докл. Казань: КАИ, 1990. 127 с.

Светомузыка на кино- и телеэкране: науч.-практ. семинар: тез. докл., 28-30 окт. 1989 г. Казань: КАИ, $1989.88 \mathrm{c}$

Синестезия: содружество чувств и синтез искусств: материалы Международной научно-практической конференции. Казань, 3-8 ноября 2008 г. / Акад. наук Татарстана, Управление культуры исполкома г. Казани, Казанский гос. технический ун-т им. А. Н. Туполева, Казанская гос. консерватория, НИИ экспериментальной эстетики «Прометей». Казань: изд-во КГТУ им. А. Н. Туполева, 2008. 360 с.

Синц̧ов E. В. Диалектика воплощаемого и возможного в мыслительных процессах: На материале творчества в искусстве: дис. ... докт. филос. наук. Екатеринбург, 1995. 381 с.

Синцуова C. B. Художественное предвидение морфологических новообразований искусства средствами словесного искусства: автореф. дис. ... канд. 
филос. Наук / НИИ экспериментальной эстетики «Прометей». Екатеринбург, 2000. 19 с.

Функциональная светомузыка на производстве, в медицине и в педагогике: Респ. науч.-практ. семинар, 22-24 окт. 1988 г.: тез. докл. Казань: КАИ, $1988.120 \mathrm{c}$.

Эйзенштейн С. Избранные сочинения: 6 т. Т. 2. М., 1964-1971. 593 c.

Электроника, музыка, свет: Материалы междунар. науч.-практ. конф., Казань, 10-14 дек. 1996 г.: (К 100-летию со дня рождения Л. С. Термена). Казань: Фэн, 1996. 299 с.

\section{Приложение}

Пат. 1324673 Российская Федерация, МПК А63J17/00. Формообразующий светоотражатель / Б. М. Галеев, Е. В. Горбунова, П. Г. Артемьев. 3967021/24-21, заявл. 21.10.1985; опубл. 23.07.1987.

Пат. 1017355 Российская Федерация, МПК А63J 17/00. Цветомузыкальный инструмент / / Б. М. Галеев - 3314035, заявл. 07.08. 1981; опубл. 05.15. 1983.

Пат. 919693 Российская Федерация, МПК А63J17/00. Светомузыкальное устройства // В. П. Букатин, Б. М. Галеев. - 2897072/ 28-21, заявл. 23. 03. 1980; опубл. 15.04.1982.

Пат. 1351617 Российская Федерация, МПК А63J17/00. Кассета для формообразователей светомузыкального устройства // В. П. Букатин, Б. М. Галеев и Р. Ф. Сайфуллин - 3901127, заявл. 27.05.1985; опубл. 15.11.1987.

Пат. 862961 Российская Федерация, МПК А63J17/00. Светомузыкальное устройство // В. Г.
Болдин, В. П. Букатин и Б. М. Галеев // 2854805/18-21, заявл. 17.12.79; опубл. 15.09.81.

Пат. 1331526 Российская Федерация, МПК А63J17/00. Выходное оптическое устройство светомузыкальной установки // Б. М. Галеев 3769744/24-12, заявл. 05.07.84, опубл. 23.08.87.

Пат. 1351618 Российская Федерация, МПК А63J17/00. Формирователь управляющих сигналов для светомузыкального устройства // В. П. Букатин, Б. М. Галеев и Р. Ф. Сайфуллин - 3901127 А1, заявл. 27.05.85; опубл. 15.11.87.

Пат. 1365023 Устройство для создания световых эффектов // Б.М. Галеев - 4101126/ 31-10, заяв. 30.07.86.; опубл. 07.01.88.

Пат. 1448167 Выходное оптическое устройство светодинамической установки // Б.М. Галеев 4274269/31-12, заявл. 20.05.87; опубл. 30.12.88.

Пат. 1540844 Электронный синтезатор светомузыкальных изображений на цветной электроннолучевой трубке // В. П. Букатин, Б. М. Галеев, Е. В. Горбунова и Р. Ф. Сайфуллин - 4226494, заявл. 9.04.87, опубл. 07.02.90.

Пат. 1569027 Светомузыкальное устройство // Б. М. Галеев, В. П. Букатин - 4460402/24-21, заявл. 9.04.87, опубл. 07.02.90.

Пат. 17005231 Светомузыкальные устройства М.: Энергия, 1978. С.131-134 // Б.М. Галеев, Р.Ф. Сайфуллин. - 3754436/10

Пат. 1719004. Выходное оптическое устройство светомузыкальной установки // Б. М. Галеев 4810741/12, заявл. 09.04.90; 15.03.92.

\title{
БУЛАТ ГАЛИЕВНЕН \\ СӘНГАТЬ ИЖАТЫН КОМПЛЕКСЛЫ ӨЙРӘНУДӘ ЭШЧӘНЛЕГЕ
}

\author{
Йолдыз Галимжан кызы Нигъмәтуллина, \\ Казан федераль университеты, \\ Россия, 420008, Казан ш., Кремль ур., 18 нче йорт, \\ ermakeev@mail.ru.
}

\begin{abstract}
Мәкаләдә Булат Мәхмүт улы Галиевнең 1970-1980 елларда Казан университетының филология факультетында барлыкка килгән сәнгать ижатын комплекслы тикшеру юнәлешенә керткән өлеше яктыртыла. Төрле профиль белгечләре, Казанда бергәләшеп, әдәбият һәм сәнгать әсәрләрен системалы-комплекслы өйрәнә башлыйлар. Әлеге хезмәттә Татарстанда яктылык сәнгате тарихы һәм теориясе белән шөгыльләнүче "Прометей” исемле студентлар конструкторлар бюросы житәкчесе Б.М. Галиевнең фәнни концепциясенә кыскача характеристика бирелә, аның күпъеллык эшчәнлегенең нәтижәләре турында мәгълүмат туплана.
\end{abstract}

Төп төшенчәләр: әдәбият һәм сәнгатьне системалы-комплекслы өйрәнү, Казан университеты, Й. Г. Нигъмәтуллина, Б. М. Галиев, «Прометей» исемле СКБ, төсле музыка теориясе. 